\title{
Vokiečiai Lietuvos ūkyje XX a. 3-4 dešimtmečiais
}

\author{
INGRIDA JAKUBAVIČIENE \\ Istoriné Lietuvos Respublikos Prezidentūra Kaune, Vilniaus g. 33, LT-44290 Kaunas \\ El. paštas: ingrida.jakubaviciene@gmail.com
}

\begin{abstract}
Straipsnyje, remiantis archyviniais šaltiniais, tuometine periodika ir statistikos duomenimis, nagrinejjama Lietuvos vokiečių žemės ūkio ir pramonès ịmonių veikla šalies ekonominiame gyvenime XX a. 3-4 dešimtmečiais, pateikiami atskirų vokiečių įmonių darbo pavyzdžiai. Lietuvos vokiečių ekonominès veiklos mastas analizuojamas remiantis vokiečių verslo Klaipedos krašte pavyzdžiais. Aptariamos Lietuvos verslo sąlygos ir konkurencijos ịtaka vokiečių ūkio plètrai, atskleidžiamas Kulturverbando vaidmuo pasinaudojant Vokietijos institucijų teikiama finansine parama, skirta stiprinti vokiečių ekonomines galias.
\end{abstract}

Raktažodžiai: Lietuvos vokiečių kultūrinė sąjunga (Kulturverbandas), Vokietija, Lietuvos vokiečių bendruomenè, Lietuvos ūkis

\section{IVADAS}

Pirmieji vokiečiai į Lietuvą galejo patekti kaip belaisviai, pirkliai ir misionieriai XIII-XV a. karų su kryžiuočių ordinu metu. Svarbiu veiksniu, tiesiogiai nulèmusiu vokiečių migraciją ị istorinės Lietuvos žemes, vokiečių istorikas R. Heberle laiko nors ir vẻlyvą, bet nuoseklų miestų ịsitvirtinimą Lietuvoje ir lietuviškų žemių ịsitraukimą i prekybą su Hanzos miestais. Vokiečių imigracija ị Lietuvą paspartėjo XIV a. viduryje ịkūrus Kauną, o ypač apie 1323 m. iškilus Vilniui [42]. 1445-1541 m. Kaune veikė 20-40 vokiečių pirklių ir tarnautojų jungusi Hanzos prekybos kontora, kuri tiesiogiai buvo pavaldi Dancigui, bet atstovavo dar ir Elbingo, Karaliaučiaus, Torūnès miestų biurgerių interesams [67]. Senoji vokiečių pirklių kolonija daug prisidejo prie Kauno, kaip viduramžių upių uosto, susiformavimo. R. Heberle's nuomone, Kauno vokiečių bendruomenė net iki XIX a. pradžios vaidino ganètinai ryškų vaidmenị miesto gyvenime, jos nariai net tapdavo burmistrais [42]. Šios istorinès aplinkybės padèjo vokiečiams plètoti ịvairius amatus. $1860 \mathrm{~m}$. kasant geležinkelio tunelị ties Kaunu, iš Vestfalijos ir Reino žemių atvykę vokiečių kalnakasiai ịsiliejo ị senajj̣ imigrantų sluoksnị. Manufaktūrinėse įmonėse ar fabrikuose, pavyzdžiui, Šakių ir Vilkaviškio žemès ùkio produkcijos perdirbimo įmonèse, Šiaulių Frenkelio odos fabrike, Panevėžio alaus ir spirito varyklose, Kauno Tilmansų (Tillmanns) (nuo 1868 m.) ir brolių Šmidtų (Schmidt) (nuo 1879 m.) metalo apdirbimo ir mašinų fabrikuose, taip pat dirbo daug vokiečių. Vien pastaruosiuose dviejuose fabrikuose jų skaičius iki Pirmojo pasaulinio karo galejjo siekti pusantro tūkstančio. Taigi Šančiuose susidarè ištisas vokiečių darbininkų kvartalas. XX a. pradžioje kai kuriose stambesnèse pramonès įmonėse Lietuvoje (vokiečių brolių Šmidtų, 
brolių Tilmansų fabrikuose Kaune, Pliaterio kartono fabrike Šiauliuose) buvo ikurtos ligonių kasos, Vokietijos pavyzdžiu vadintos „krankasėmis“. Jos aptarnavo tik minètų fabrikų tarnautojus ir darbininkus [81]. Dalis prieš Pirmąji pasaulinị karą veikusių vokiečių i̇monių XX a. 3-4 dešimtmečiais savo veiklą dar labiau išplètè. Vokiečiai daug prisidèjo prie Lietuvos industrializavimo ir žemès ūkio mechanizacijos, ypač vakarinejje šalies dalyje. Jiems priklausę dvarai iki pat $1922 \mathrm{~m}$. žemès reformos buvo laikomi pavyzdiniais, kadangi čia buvo plètojama sejjomaina ir diegiamos agrarinès naujovès.

1923 m. Lietuvoje (dar be Klaipėdos krašto) gyveno 29231 vokietis, arba 1,44 \% visų gyventojų. Vokiečių bendruomenės branduolys Vilkaviškio apskrityje sudarė 12,46 \% apskrities gyventojų, Šakių apskrityje - 4,3 \%, Tauragés apskrityje - 3,4 \%, Marijampolès apskrityje - 3,42\%, Raseinių apskrityje - apie $2 \%$ ir Kauno mieste - 3,54 \% visų gyventojų [49]. Kur kas geresnes ekonomines pozicijas vokiečiai turejjo Klaipėdos krašte: 1925 m. gyventojų surašymo duomenimis, čia gyveno 64158 vokiečiai, arba 45 \% visų krašto gyventojų [85]. Nors ši tautinẻ bendruomenẻ buvo gana nedidelè ( $4,1 \%$ visų šalies gyventojų), tačiau vaidino gana svarbų vaidmeni šalies ekonominiame gyvenime.

Lietuvoje, kaip ir Klaipėdos krašte, ne tik veikẻ keli šimtai mažesnių ir didesnių Lietuvos vokiečių i̇monių, bet ir dešimtys stambių Vokietijos kapitalo kompanijų, kuriose nuolat dirbo keli šimtai Vokietijos piliečių. Lietuvoje vokiečiai naudojosi slaptomis ir nelegaliomis Vokietijos kredito bendrovemis, teikiančiomis kreditus Vokietijos interesais besirūpinantiems asmenims. Ketvirtajame dešimtmetyje vokiečių įmonès susidūrẻ su stiprèjančia lietuvių konkurencija bei valstybiniu lietuviškų ịmonių protegavimu, ir tai turèjo neigiamų pasekmių vokiečių verslui.

Svarbų vaidmeni vokiečiu ūkiniame gyvenime, ypač Klaipėdos krašto ekonomikoje, suvaidino Vokietija. Ketvirtajame dešimtmetyje vokiečių tautinès organizacijos, pritrūkusios finansinių išteklių vokiečių kultūrinei ir ūkinei veiklai, vis dažniau prašè pagalbos iš Vokietijos. Mainais už finansinę paramą Vokietija reikalavo palaikyti jos politinius interesus Lietuvoje. Taigi vokiečių verslo sèkmè tapo tiesiogiai proporcinga gaunamai paramai iš Vokietijos. Ši teigini geriausiai patvirtina vokiečių ūkinès veiklos rezultatai Klaipèdos krašte. Apie Klaipedos krašto vokiečių verslo įmonių sąsajas su Vokietija pirmoji tyrimus paskelbė istorikè Petronèlè Žostautaitè $[87,88,89]$. Klaipèdos krašte veikusių vokiečių bankų ir kredito bendrovių veiklos gilesnę analizę pateikè ekonomistas Vladas Terleckas [82], naujausius Klaipėdos krašto ūkio istorijos tyrimus atliko Julius Žukas [88, 89]. Šio straipsnio autorè savo publikacijose jau yra analizavusi Lietuvos vokiečių bendradarbiavimą su įvairiomis Vokietijos institucijomis ir šių ryšių įtaką vokiečių politinei, kultūrinei ir ūkinei veiklai [75]. Lietuvių istoriografijoje daugiausia dèmesio skirta $1941 \mathrm{~m}$. ̣̇ Vokietiją iškeldintų vokiečių palikto ir išvežto turto apskaičiavimams, kurie byloja apie 4-ojo dešimtmečio pabaigos vokiečių ekonominius laimèjimus, valdyto turto dydị. Vytautas Venskūnas tyrè vokiečių išvežtą ir paliktą Lietuvoje nekilnojamąjj ir kitą turtą [84]; iškeldinamų vokiečių Lietuvoje valdytu turtu bei jo verte domèjosi istorikè Arūnė Arbušauskaitė [69], statistikos duomenų apie vokiečių i̇monių veiklą pateikẻ Saulius Kaubrys [77]. Gana epizodiškai savo tyrimuose Lietuvos vokiečių ūkinę veiklą palietė Vokietijos istorikai Norbertas Angermanas [67], Rudolfas Heberle [42], Haris Stosunas [80], Klausas Fuchsas [72, 73].

Kadangi ši tema yra menkai ištyrinèta, straipsnyje autore dažnai remiasi Lietuvos centrinio valstybės archyvo (toliau LCVA) medžiaga: Lietuvos Respublikos vidaus reikalų ministerijos fondo (f. 377), Lietuvos Respublikos vidaus reikalų ministerijos Saugumo departamento fondo (f. 378), Lietuvos Respublikos užsienio reikalų ministerijos fondo (f. 383), 
Lietuvos Respublikos vidaus reikalų ministerijos Policijos departamento fondo (f. 394), Lietuvos Respublikos Ministrų kabineto fondo (f. 923) dokumentais. Medžiaga apie Kaune veikusias stambias vokiečiu įmones saugoma Kauno apskrities archyve (f. 209). Svarbiais šaltiniais tapo Lietuvos statistikos metraščiai, pirmojo Lietuvos gyventojų surašymo duomenys [49], tuometiné periodika, pramonès įmonių registrai bei publikuotų dokumentų rinkiniai $[7,9]$.

Straipsnio objektas - vokiečių dalyvavimas Lietuvos ekonominiame gyvenime XX a. 3-4-uoju dešimtmečiais; tikslas - ištirti Lietuvos vokiečių verslo i̇monių veiklos kryptis, ekonominès veiklos apimtis ir rezultatus, jų prisitaikymą prie verslo sąlygų šalyje; uždaviniai: 1) atskleisti Lietuvos vokiečių ūkinès veiklos ypatumus, 2) išanalizuoti Kulturverbando vaidmenị stiprinant vokiečių ekonomines galias Lietuvoje, 3) atskleisti Vokietijos teikiamos finansinès ir politinès paramos įtaką stiprinant vokiečių ekonominius rezultatus.

Tyrimo metodai: istoriografinis, analizès ir sintezès, archyvinių šaltinių ir literatūros analizès.

\section{VOKIEČIŲ PRAMONĖS, PREKYBOS IR FINANSŲ IMONIŲ VEIKLA LIETUVOJE}

Lietuvos vokiečių bendruomenès socialinè struktūra ženkliai skyrèsi nuo jų tautiečių Latvijoje bei Estijoje, kur vokiečiai daugiausia gyveno miestuose ir turèjo savo verslą ar dirbo pagal profesiją. Lietuvoje du trečdaliai vokiečių gyveno kaimuose ir vertèsi žemès ùkiu arba amatais. 1923 m. gyventojų surašymo duomenimis, Didžiosios Lietuvos miestuose gyveno 10 132, arba 3,4\%, miesteliuose - 2 104, arba 1,1\%, o kaimuose - 16 995, arba $1,1 \%$ vokiečių [49]. Kadangi daugiausia vokiečių gyveno Lietuvos kaimuose, žemès ūkyje dirbo 10836 asmenys, arba $37 \%$, pramonèje - 3 070, arba 10,5\%, užsièmè amatais ar buvo samdomi darbuotojai - 2 831, arba 9,68 \%, transporto ir susiekimo srityje dirbo 473, arba $1,6 \%$, prekyboje - 466, arba 1,6\%, valstybès tarnyboje bei visuomeniniame darbe - 809 asmenys, arba 2,76\% [49]. Galima teigti, kad vokiečiu socialinė padètis po Lietuvos nepriklausomybės paskelbimo $1918 \mathrm{~m}$. beveik nepakito, tuo tarpu Latvijoje ir Estijoje ji gerokai pablogejjo - vokiečiai neteko valdančiųų pozicijų, nors dauguma jų liko gyventi miestuose ir priklause aukštam socialiniam sluoksniui.

Vokiečiai buvo sèkmingai integravęsi ị Lietuvos ekonominị ir visuomeninị gyvenimą. Iš Lietuvos kilęs vokiečių istorikas Arthuras Hermannas rašè: „<...> prieškarinèje Lietuvoje vokiečiai niekur negyveno gausiai, išskyrus Šančius ir keletą dvarų. Jie gana anksti pradejo net namuose kalbėti lietuviškai ir savo socialine padėtimi ne ką skyrèsi nuo lietuvių, nes buvo daugiausia ūkininkai ir amatininkai" [74]. Iš tiesų nemaža dalis vokiečių buvo gerokai paveikti lietuvių kultūros - mat gyveno mišriose santuokose su lietuvių tautybès sutuoktiniais. Prieškariu didelị vaidmenị santuokoje vaidino konfesinė priklausomybè vienai ar kitai bendruomenei. Remiantis Lietuvos statistikos metraščio duomenimis apie 1928-1938 m. vokiečių sudarytas santuokas, 25,3 \% santuokų buvo mišrios - vokiečių ir lietuvių evangelikų $[53,54,55,56,57,58]$. Albinas Juška atsiminimuose teigia, jog lietuvių ir vokiečių santykiai buvo normalūs, žmoniški, tačiau lietuviai jiems galèjo pavydèti gražesnių pastatų, dosnesnių dirvų, kultūringesnès aplinkos [76]. Pažymėtina, kad vokiečių bendruomenès raštingumas buvo gana aukštas: 58,4 \% vokiečių mokejjo ir skaityti, ir rašyti, 10 \%okejjo tik skaityti [49]. Pasak Jono Mardosos, tyrusio tautinius santykius Lietuvos miesteliuose ir kaimuose, 1920-1940 m. vokiečiai buvo integravęsi ị savo gyvenamosios aplinkos socialinị, kultūrinị gyvenimą, todèl aplinkiniai jiems buvo palankūs, o kilus socialiniams konfliktams, tautine priklausomybè netapdavo papildomu konflikto katalizatoriumi. Taip buvo 
1 lentelè. Vokiečių darbo sritys (pagal $1923 \mathrm{~m}$. Lietuvos gyventojų surašymo duomenis)

\begin{tabular}{|c|c|c|c|c|}
\hline Darbo sritis & Vyru & Motery & Iš viso & Proc. \\
\hline \multicolumn{5}{|l|}{ Žemès ūkyje } \\
\hline Šeimininkai & 2063 & 252 & 2315 & \\
\hline Dirbantys šeimos nariai & 2049 & 4568 & 6617 & \\
\hline Tarnautojai & 18 & - & 18 & \\
\hline Darbininkai & 1110 & 776 & 1886 & \\
\hline Iš viso & 5240 & 5596 & 10836 & $37 \%$ \\
\hline \multicolumn{5}{|l|}{ Pramonejje } \\
\hline Šeimininkai & 752 & 92 & 844 & \\
\hline Dirbantys šeimos nariai & 288 & 249 & 537 & \\
\hline Tarnautojai & 88 & 14 & 102 & \\
\hline Darbininkai & 1312 & 275 & 1587 & \\
\hline Iš viso & 2440 & 630 & 3070 & $10,6 \%$ \\
\hline \multicolumn{5}{|l|}{$\begin{array}{c}\text { Transporte bei } \\
\text { susisiekimo srityje }\end{array}$} \\
\hline Šeimininkai & 7 & - & 7 & \\
\hline Dirbantys šeimos nariai & 3 & 1 & 4 & \\
\hline Tarnautojai & 84 & 28 & 112 & \\
\hline Darbininkai & 343 & 7 & 350 & \\
\hline Iš viso & 437 & 36 & 473 & $1,6 \%$ \\
\hline \multicolumn{5}{|l|}{ Prekyboje } \\
\hline Šeimininkai & 96 & 20 & 116 & \\
\hline Dirbantys šeimos nariai & 20 & 21 & 41 & \\
\hline Tarnautojai & 145 & 45 & 190 & \\
\hline Darbininkai & 79 & 40 & 119 & \\
\hline Iš viso & 349 & 126 & 466 & $1,6 \%$ \\
\hline \multicolumn{5}{|l|}{$\begin{array}{l}\text { Valstybès bei visuomeninèse } \\
\text { jstaigose }\end{array}$} \\
\hline Šeimininkai & 53 & 40 & 93 & \\
\hline Dirbantys šeimos nariai & - & - & - & \\
\hline Tarnautojai & 448 & 122 & 570 & \\
\hline Darbininkai & 128 & 18 & 146 & \\
\hline Iš viso & 629 & 180 & 809 & $2,8 \%$ \\
\hline \multicolumn{5}{|l|}{ Kiti gyvenimo šaltiniai } \\
\hline Šeimininkai & 91 & 1278 & 1369 & \\
\hline Dirbantys šeimos nariai & 20 & 500 & 520 & \\
\hline Tarnautojai & 3 & 5 & 8 & \\
\hline Darbininkai & 375 & 559 & 934 & \\
\hline Iš viso & 489 & 2342 & 2831 & $9,7 \%$ \\
\hline $\begin{array}{l}\text { Iš viso savarankiškų } \\
\text { gyventojų }\end{array}$ & 9575 & 8910 & 18485 & $63,3 \%$ \\
\hline Nesavarankišku & 4772 & 5971 & 10743 & $36,7 \%$ \\
\hline Nežinomi pragyvenimo šaltiniai & 2 & 1 & 3 & \\
\hline Iš viso & 14349 & 14832 & 29181 & $100 \%$ \\
\hline
\end{tabular}

Šaltinis: VIII. Lietuvos gyventojai darbo sritimis ir tautybemis. Lietuvos gyventojai. Pirmojo 1923 m. rugsejo 17 d. visuotino gyventoju surašymo duomenys. Kaunas, 1924, p. 295. 
visų pirma todèl, kad vokiečiai, atrodo, buvo besąlygiškai sutikę su savo statusu ir neturèjo nepagrịstų tautinių ambicijų [79]. Gerą vokiečių prisitaikymą prie esamos padèties ir menką dar geresnių sąlygų siekị rodo ir nedidelis noras emigruoti iš Lietuvos: 1928-1938 m. emigravo 533 vokiečiai, kurie tesudarė 1,3\% visų emigrantų iš Lietuvos [58].

$1918 \mathrm{~m}$. vasario $16 \mathrm{~d}$. paskelbus Lietuvos nepriklausomybę, vietos vokiečiams iškilo būtinybė prisitaikyti prie naujų politinių aplinkybių. Kol Lietuvos vokiečiai jautė valdžios prielankumą ir kitų tautinių grupių korektišką laikyseną, tai iš esmès atitiko jų pačių interesus - nesivelti ì politiką ir ramiai plètoti savo ekonominę veiklą [80].

Kalbant apie vokiečių dalyvavimą šalies ekonominiame gyvenime, būtina paminèti žymiausius vokiečių partijos (Partei der Deutschen Litauens) veikẻjus Rudolfą Kinderị, banko direktorių A. Rogali (Rogall), Kauno prekybininką O. Šulcą (Schulz), valdininką Liudviką Deringą ir kitus. $1924 \mathrm{~m}$. ̣̇ Kauno miesto tarybą, kurią sudare 68 nariai, ịejo L. Deringas, R. Kinderis, Vilhelmas Krukas, Jokūbas Rufas. Lietuvos vokiečiams Silvijus Brioderichas (Bröderich) buvo svarbus ne tik dèl iniciatyvos steigti Kauno vokiečių gimnaziją, bet ir dèl užimamų Lietuvos vyriausybės agrarinių reikalų patarẻjo pareigų.

Tuometinejje Lietuvoje verslas buvo privačios iniciatyvos sritis. Stambesnès bendrovès, kooperatyvai bei jų sąjungos užsièmė didmenine ir užsienio prekyba. Stambiąsias akcines bendroves kontroliavo ir valstybè, supirkusi privataus ūkio neišpirktas akcijas, tačiau specialios valstybės priežiūros prekybos ịstaigoms Lietuvoje nebuvo. Prekybos įmones prižiūrèję mokesčių inspektoriai rūpinosi tik mokesčiais. $1934 \mathrm{~m}$. daugiausia verslo licencijų vokiečiams buvo išduota maisto gamybos srityje - 78, medienos apdirbimo srityje - 19, drabužių ir avalynès - 14, metalo ir mašinų gamyboje - 10, tekstilès įmonėms - 10, žemès ir akmens apdirbimo - 9, sanitarinių paslaugų - 3, chemijos įmonėms - 2, kailiadirbystès imonei - 1, spaustuvei - 1, elektros gamybos įmonei - 1; iš viso vokiečių tautybès asmenims buvo išduotos 148 verslo licencijos [77]. $1938 \mathrm{~m}$. Lietuvoje buvo 25514 prekybos įmonių, išpirkusių patentus verstis prekyba, iš jų 18480 ịmonių vertèsi prekyba, o likusios 7034 buvo įvairios aptarnavimo įmonès: vaistinès, kino teatrai, restoranai, užkandinès, kioskai, viešbučiai ir pan. 1938 m. vokiečiai valdè 255 įmones: 92 malūnus, 88 ịvairių prekių parduotuves, 49 gamyklas ir įmones, 5 kirpyklas, 4 emigracijos ir turizmo biurus, 4 plytines, 3 alaus ir spirito daryklas, 3 vaistines, 3 elektrines, 2 akcines bendroves, vieną knygyną, vieną kino teatrą $[18,77]$. Gana nedaug vokiečių dalyvavo ekonominių ir profesinių draugiju veikloje. Remdamiesi $1931 \mathrm{~m}$. organizacijų statistikos duomenimis, galime teigti, jog tik 361 vokietis priklause ekonominèms organizacijoms, 77 - profesinėms draugijoms, kai tuo tarpu blaivybės organizacijoms priklausè 627 , religinèms - 480, sporto - 265 , o kultūros - 1924 vokiečių [3]. Taigi vokiečiai Lietuvos verslo aplinkoje sudare tik nedidelę dalị.

Lietuvos vokiečiai daugiausia priklausè smulkiajam verslui. Jų ekonominès galimybès ženkliai skyrèsi nuo Klaipėdos krašto vokiečių verslo atstovų. Tik 4-ojo dešimtmečio pabaigoje padaugejo Lietuvos vokiečių valdomų fabrikų ir stambesnių įmonių. Lietuvos vokiečiai negalejjo pasigirti tokia tankia koncentracija viename regione, kaip, pvz., Klaipėdos krašte, kur vokiečiai sudarẻ bemaž pusę krašto gyventojų ir dẻl istoriškai susiklosčiusių sąlygų priklausẻ aukštesniam socialiniam sluoksniui, tarnavo ịvairiose krašto administracijos ịstaigose. Tai padėjo vokiečiams įsitvirtinti visose pramonės bei ūkio šakose. Klaipėdos krašte vokiečiams priklausè stambiausi fabrikai (Celiuliozès ir popieriaus fabrikas, faneros fabrikų akcinè bendrovė „Bisdom u. Zoon“, laivų statybos įmonė „Lindenau ir ko“, trąšų fabrikas „Union“, keturi tabako fabrikai), keliolika smulkių baldų gamybos i̇monių ir lentpjūvių, kelios alaus daryklos ir spirito varyklos, metalo ir mašinų, muilo ir skalbimo priemonių 
gamybos įmonès, dujų įmonès, durpių gamybos įmoné Šilutėje, elektrinių baterijų įmonės, saldainių, biskvitų ir vaflių kepyklos [85].

Lietuvos vokiečiu verslo pasididžiavimu laikytas R. Tilmansas ir jo ịmonès. R. Tilmansas gimė Vokietijoje, Reino žemėje. 1878 m. atvykęs ị Kauną ịsteigè pirmąji Rusijoje metalo dirbinių fabriką, kuris pagal dydị buvo pirmasis Rusijoje bei antras Europoje; čia dirbo 2 tūkst. darbininkų. R. Tilmansui rūpejjo ne tik savo fabriko, bet ir miesto reikalai. Iki Pirmojo pasaulinio karo jis buvo Kauno miesto dūmos narys, ̣̦steigé Kaune komercijos mokyklą, už nuopelnus iš caro buvo gavęs komercijos patarèjo titulą. Po Pirmojo pasaulinio karo R. Tilmansas ịkūrè ir vadovavo daugeliui žinomų įmonių: buvo Lietuvos komercijos banko steigèjas ir priežiūros komisijos pirmininkas, saldainių ir kakavos fabriko „Tilkos“ steigèjas ir priežiūros tarybos pirmininkas, Lietuvos „Loydo“ bendrovès steigejjas. Šis pramonininkas gausiai rèmè Kauno vokiečių gimnaziją, evangelikų bažnyčias ir įvairias vokiečių labdaros draugijas $[47,63]$.

R. Tilmansui priklausė geležies ir statybos medžiagų fabrikas „Br. Tillmanns ir ko. AB“, kuriame dirbo 130 darbininkų ir 12 tarnautojų [30]. 1925 m. Kauno miesto mokesčių inspekcijos duomenimis, „Br. Tillmans ir ko. AB“ fabriko nekilnojamojo turto vertè siekè $2 \mathrm{mln}$. 330 tūkst. Lt, o fabriko kilnojamasis turtas įkainotas daugiau nei $5 \mathrm{mln}$. Lt, todèl akcinis kapitalas sudarè $8 \mathrm{mln}$. Lt [2]. $1937 \mathrm{~m}$. apskaitos metų pelnas sudare $53569 \mathrm{Lt}$ [13], 1939 m. - 280331 Lt ir 68 ct [20]. Fabrikas gamino sraigtus, varžtus, kniedes, vinis, plieninius ir valcuotos geležies dirbinius [50]. Visą laiką pelningai dirbusi įmonė 4-ajame dešimtmetyje susidūrè su didele vidaus konkurencija. Dèl to įmonė nebebuvo plečiama, dalis nebenaudojamų patalpų buvo išnuomotos kitoms bendrovėms. Dẻl ekonominès konkurencijos fabriko administracija gana ženkliai sumažino darbininkų skaičių (kai kurie jų patys ėmèsi naujo verslo). Fabrikas įdomus ir architektūriniu požiūriu, ypač 1914 m. pastatyta mechanine kalve ir Marteno krosnių korpusu. Tilmansai fabriką valdè iki 1940 m., o $1941 \mathrm{~m}$. jis buvo nacionalizuotas [78].

Tilmansų šeima buvo Kauno priemiestyje Šančiuose $1921 \mathrm{~m}$. įkurto „Tilkos“ šokolado fabriko dalininkè. 1930 m. „Tilka“ gamino apie 100 rūšių šokolado, apie 200 rūšių ịvairių pavadinimų saldainių, puikią kakavą, kuri savo kokybe pralenkè užsieninę. „Tilkos“ fabrike dirbo tik 160 darbininkų, nes didžiąją darbo dali atliko naujausios mašinos [36]. Ketvirtajame dešimtmetyje, kada lietuviškas kapitalas ėmè veržtis i sėkmingai veikiančias kitataučių valdomas bendroves, vèlesniuose straipsniuose apie „Tilkos“ veiklą buvo pabrèžiama, kad „Tilka“ yra lietuvių nuosavybè, o jos direktorius Kaminskas ir visi darbininkai - lietuviai [59]. Iš tiesų fabriko dalininku visą laiką buvo Tilmansų šeima, jame, nors ir buvo sulietuvinto personalo, visą laiką dirbo vokiečiai (pvz., chemikas daktaras Šenbergas (Schönberg)) ir kitų tautybių asmenys. İsibėgejus verslo lietuvinimo akcijai, įmonių veikloje stengtasi kuo mažiau akcentuoti kitataučių darbininkų darbą, taip pat kokios tautybès asmenys sudaro įmonès priežiūros komisiją.

Gana garsus ne tik Lietuvoje, bet ir už jos ribų buvo metalo dirbinių ir mašinų fabrikas, kurị Kauno Šančių rajone 1879 m. ịkūrè vokiečiai broliai Šmidtai. Fabrikas, kurio kapitalas siekė 7,5 mln. Lt, gamino vielą, vinis, grandines, geležinius žemės ūkio padargus, cinkuotus indus ir talpas, lygintuvus, rankenas, vyrius, spynas [50]. Aptariamuoju laikotarpiu brolių Šmidtų metalo fabrikas (vèliau pavadintas AB „Metalas“) lygiomis dalimis priklausè broliams Jonui ir Juozui Vailokaičiams, todèl šis fabrikas iš vokiškos tapo lietuviško kapitalo i̇mone, tačiau jame dirbo nemažai vokiečių kilmès tarnautojų ir darbininkų: 1937 m. fabriko darbuotojų sąrašuose aptinkame inžinierių Praną Hiksą, kasininką Artūrą Lineburgerị, sandèlio vedèją Joną Heldkę, tarnautoją Augustą Šmidtą [14]. 
Galime teigti, jog vokiečiai pirmavo žemės ūkio mašinų ir automobilių pardavimo, geležies prekių gamybos ir prekybos, elektrotechnikos srityse. Geležies dirbinių parduotuvès Kaune priklausė Bèrui ir Švarcui, Otui Malsui, I. Šneidersui, „Vogau ir Ko“. Žemès ūkio mašinų ir traktorių pardavimu Kaune vertėsi I. Malstroemas, M. Meyeris, o Panevėžyje - Štėgeris ir Šefleris bei K. Sprigastas [51]. Elektrotechnikos dalimis Kaune prekiavo Otas Hesė (Hesse) ir E. Rupertas, automobiliais ir dviračiais Kaune - Erhardo Zomerio (Sommer) ir Valdenbergo firmos [51]. E. Zomerio firma, kurta 1915 m., 3-iajame dešimtmetyje Lietuvoje pirmavo pagal „General Motors“ automobilių pardavimą. Ši įmonè pirmoji pradèjo importuoti benziną ir naftos produktus, o nuo $1925 \mathrm{~m}$. ne tik importavo automobilius, bet ir gamino omnibusus, prekinius automobilius, gaisrinius ir asenizacijos automobilius [52]. Richardui Zomeriui Kaune priklausė nedidelè prekybos ir pramonès reikmenų i̇monė [34].

Marijampoleje garsiausios vokiečių i̇monès technikos biuro ir mašinų dirbtuvès savininkas buvo inžinierius K. Vitmozeris. Jo įmonè, įsteigta 1912 m., buvo oficiali „Heinrich Lanz“ bendrovès Manheime, gaminusios kuliamąsias mašinas ir traktorius, motorų gamyklos Darmštate, dyzelinių motorų „Modaag“, malūnų mašinų gamintojų „Heinrich Bock“ atstovè Lietuvoje [52]. K. Vitmozerio įmonè taip pat gamino žemès ūkio mašinas, įrenginèjo vandentiekị ir centrinị namų šildymą [50]. Šakių apskrityje veikè vienas stambus Žemès ūkio mašinų ir įrankių fabrikas bei viena ketaus liejykla, kurios priklausė Eugenijui Malcanui. 1901 m. ịsteigta įmonė gamino kuliamąsias mašinas, ̣̂vairių tipų akéčias, žemės lygintuvus [50]. Radviliškyje nuo 1922 m. veikè inžinieriaus Johano Fehlauerio įmonė, gaminusi mazutinius variklius ir išcentrinius siurblius [50].

Žymūs vokiečių inžinieriai valdè Kauno elektros stotį. Nors ją 1900 m. įsteigè Belgijos pilietis F. Šmatceris, tačiau nuo 3-iojo dešimtmečio ji priklausè „Elektros šviesos Kauno miestui apšviesti akcinei bendrovei“, kuriai vadovavo valdybos pirmininkas dr. R. Šleunas (Schleun) ir direktorius-valdytojas inž. A. Langè. I valdybą įèjo inž. Šliogeris, P. Hefordas, inž. E. Langè, inž. G. Somerhausenas ir P. Freiteris (Freiteur) [52]. Vokiečiai buvo ir stambių i̇monių akcininkai: antai Erichui Fišeriui priklausè dalis tabako ir cigarečių fabriko „Kontinental“ [30].

Daugiausia vokiečių i̇monių veikè Kaune: Fridrichui Šènui Kaune priklausė avalynès dirbtuvè „Sport“, kurioje dirbo aštuoni darbininkai; Karoliui Mannui - santechnikos ir šaltkalvių dirbtuvès su dešimčia darbininkų; Gustavui Fridrichui Vinkšui - automobilių remonto dirbtuvès su septyniais darbininkais, Erichui Liutzkendorfui - vandentiekio sistemų dirbtuvė, Klarai Moricienei - moterų kirpykla, Augustui Šlemingeriui - mėsinè, Erichui Bergeneriui - nèrinių dirbtuvė [30]. Muzikos instrumentais Kaune prekiavo C. Šiutcas (Schütze) bei O. Špileris, H. Mozerio bendrovè. Indų ir stiklo prekyba Kaune vertèsi Hermanas Hilcas ir C. Šiutcas [51].

Kèdainių apskrityje vokiečiams priklausè septynios nedidelès įmonès: Karolis Šrèderis (Schröder) ir Aleksanderis Mileris valdè odų dirbtuves, Povilas Kinulis ir Adomas Bodendorfas buvo molinių puodų dirbtuvès savininkai, Viliui Šmidtui priklausė kalvė. Marijampolès apskrityje buvo 15 vokiečiu i̇monių: mėsines valdè broliai Otas ir Oskaras Jurkšaičiai, Jokūbas Baura, mašinų remonto dirbtuves turèjo Albertas Bretšneideris bei Adolfas Mauris, kailių dirbtuvę - Osvaldas Jègeris, baldų dirbtuves - broliai Gustavas ir Leopoldas Dromeliai bei Rudolfas Reinertas, kepyklą - Henrikas Šlefoktas, avalynès dirbtuvę-Vilius Chozinaitis, aliejaus spaudyklą - Adolfas Torkleris [30]. Šiauliuosegeležies dirbinių prekyba vertėsi D. Grundbergas [51]. Biržų, Kretingos, Panevėžio apskrityse veikè vos po vieną stambesnę vokiečių įmonę, o Mažeikių apskrityje vokiečiams priklausė trys įmonès [30]. 
Panevėžyje veikè vokiečių alaus darykla. Vokiečių kilmės dvarininkas Albertas Foigtas 1902 m. ịkūrẻ Panevėžio alaus daryklą ir romantiškai pavadino ją „Bergschlosschen“" (Pilaitė ant kalvos). 1918 m. pavadinimas buvo pakeistas ị lietuvišką „Kalnapilis“. Panevėžio apskrityje Richardui Krauzei priklausiusioje svarstyklių dirbtuvejje dirbo aštuoni darbininkai. Kretingoje Haris Šliteris turẻjo vilnų verpyklą, kurioje dirbo aštuoni darbininkai. Mažeikių apskrityje veikè Oto Ilterio mèsinè, Franko Bergau milo dažykla bei Ricardo Vintelerio vilnų verpykla. Telšių apskrityje Aleksas Neimanas (Neumann) turëjo šaltkalvę [30].

Ketvirtojo dešimtmečio viduryje Lietuvos saugumo organai atidžiau stebejo vokiečiu immonių veiklą, siekè nustatyti galimus tiesioginius ryšius su Vokietija, išsiaiškinti įmonès savininkų politines pažiūras. Dauguma Lietuvos vokiečių ịmonininkų ir jų darbininkai dokumentuose apibūdinami kaip lojalūs Lietuvai. Tik keli įmonių savininkai, remiantis jų viešai išsakytomis simpatijomis Vokietijai bei priklausymu vokiečių kultūrinei sąjungai Kulturverbandui (vok. Kulturverband der Deutschen Litauens) [30], ịvardyti kaip smarkūs vokietininkai.

Lietuvos vokiečių verslui nuolat stigo finansinės paramos. Verslui plètoti vokiečiai savo iniciatyva steigé smulkius kredito bankus. Smulkios vokiečių kredito, dar vadinamos savitarpio pagalbos, bendrovès veikè Marijampoleje, Virbalyje, Naumiestyje, Šakiuose ir Raseiniuose [27]. Vienas pirmųjų tokių bankų - Šančių smulkaus kredito bankas, ịsteigtas Kaune 1924 m., veikè iki pat 1940 metų [28]. Daug stambesnis buvo Vokiečių smulkaus kredito bankas, ịkurtas Kaune. Jam 1933 m. vadovavo A. Kurkauskas, E. Langè, A. Herfordas, A. Pašakarnis, S. Fanstilis, K. Balbachas, H. Domela. 1933 m. banko aktyvą sudarė $2 \mathrm{mln}$. 422927 Lt. Banko vyr. finansininkas buvo V. Krukas [35]. Šiam bankui priklausė 1300 akcininkų indèlių. Problemos banke prasidejo $1934 \mathrm{~m}$. pradžioje, kada skolininkai nepajègè grąžinti kreditų, todèl vasarą bankas Kauno apygardos teismo nutarimu buvo paskelbtas subankrutavusiu [5]. Daugiausia kreditų gavo amatininkai, ūkininkai, žemesniųjų kategorijų tarnautojai. Remdamasi skolinamųjų-taupomųjų kasų ir mažų bankelių ịstatymu, valdžia reikalavo, kad banko valdyba skoloms padengti sumoketų trigubą pajaus mokesti. Tiriant paaiškejjo, kad kai kurie banko nariai gavo paskolų daugiau kaip 100 tūkst. Lt, nors tai draudè banko įstatai [26].

1933 m. vokiečių bendruomenę vienijančia organizacija tapo dar 1924 m. ikurta Lietuvos vokiečių kultūrinè sąjunga, sutrumpintai vadinama Kulturverbandu. Iki 3-iojo dešimtmečio pabaigos Kulturverbandas veikè savarankiškai, su Vokietija palaikydamas tik minimalius ryšius ir gaudamas nedidelę finansinę paramą iš Vokietijoje veikusios „Draugijos vokiečiams užsienyje remti“ (Verein für das Deutschtum im Auslände - V. D. A.) bei Vokietijos fondo (Deutsche Stifftung). Tačiau $1931 \mathrm{~m}$. su Rytprūsių vokiečių tautinių organizacijų bei Vokietijos užsienio reikalų ministerijos žinia buvo pakeista visa Kulturverbando valdyba ir organizacijai buvo pavesta rūpintis ne tik kultūrine-tautine veikla, bet ir politiniais, ekonominiais bendruomenès interesais. Kadangi ši sąunga nuo 4-ojo dešimtmečio pradžios rūpinosi visais bendruomenès reikalais, todèl Kulturverbando valdyba kreipèsi ị Vokietijos pasiuntinybę Kaune ir dèl finansinès paramos atgaivinti subankrutavusị vokiečių banką.

Vokiečiu verslo kreditavimo klausimas buvo aktualus stambiems dvarininkams. Jų interesus gerai suprato svarbiausios vokiečių organizacijos - Kulturverbando - pirmininkas dvarininkas Oskaras fon Reichardas. 1936 m. balandi i j Kulturverbando Centro valdybos būstinę atvykę keli stambūs Lietuvos vokiečiai dvarininkai Pilas (Pillau), fon Grotas (von Grotthuss), fon Bèras (von Beer) siūlè atidaryti naują kredito draugiją, kuri perimtų visus senojo banko reikalus. Vokiečių banko atgaivinimo reikalu per Kulturverbando vadovybę buvo kreiptasi 
$\mathfrak{i}$ atsakingas Vokietijos institucijas. Buvo prašoma skirti 2,5 mln. litų paramą ir tai padaryti per artimiausius porą mėnesių [8]. Negavus finansinès pagalbos iš Vokietijos, banko veikla nebuvo atgaivinta.

Daug geresnè vokiečių finansinių institucijų padètis buvo Klaipėdos krašte. Čia veikusiems bankams: Klaipėdos bankui (Memeler Bank), Ūkio bankui (Landschftsbank), Raifeizeno bankui (Reifeisen Bank) su 38 žemès ūkio kredito kooperatyvais bei Klaipėdos miesto taupomajai kasai niekada negrèsè bankrotas. Plètoti ekonominę veiklą Klaipėdos krašto vokiečiams ženkliai padejjo ir Vokietijos finansinès institucijos, kurios teikè paramą per slaptas ir legaliai veikusias Klaipèdos krašto kredito bendroves.

Su vokiečių ekonomine veikla Lietuvoje buvo susiję ’̇ Lietuvą atvykę keli šimtai Vokietijos piliečių darbo ar verslo reikalais. 1932 m. duomenimis, Lietuvoje (be Klaipèdos krašto) gyveno 297 Vokietijos piliečiai, turintys darbo leidimus. Be to, Didžiojoje Lietuvoje gyveno dar 477 Vokietijos piliečiai, kuriems darbo leidimai nebuvo reikalingi [4]. Vokietijos piliečiai Lietuvoje nuo $1921 \mathrm{~m}$. buvo susibūrę ị Vokietijos piliečių sąjungą (Verein der Reichsdeutschen). Ši sajunga rengè susirinkimus R. Tilmanso namuose Kaune, kuriuose turèjo savo klubą. I ji rinkdavosi ne tik stambiojo vokiečių kapitalo atstovai, bet ir Lietuvos pilietybę turintys vokiečiai. Klubui vadovavo Lietuvos komercijos banko direktorius Povilas Hofmanas (Hoffmann) [33]. 1935 m. sausio 1 d. statistikos duomenimis, iš viso Lietuvoje gyveno 2621 Vokietijos pilietis, iš jų Didžiojoje Lietuvoje - 720, arba 27,5 \%, ir Klaipèdos krašte - 1 901, arba 72,5 \% [56]. 1937 m. sausio 1 d. duomenimis, Lietuvoje gyveno 1738 Vokietijos piliečiai, iš jų Didžiojoje Lietuvoje - 497, arba 28,6 \%, ir Klaipėdos krašte - 1 241, arba 72,4 \% [57]. Bemaž pusė į Didžiąją Lietuvą atvykusių Vokietijos piliečiu gyveno Kaune, po kelias dešimtis jų dirbo Šiauliuose, Marijampoleje, Taurageje, Vilkaviškyje, Šakiuose. Dalis Vokietijos piliečių atvykdavo su šeimomis, todèl pusė jų buvo išlaikomi dirbančių šeimos narių. Dirbantieji Vokietijos piliečiai beveik lygiomis dalimis dalijosi penketą ùkio sričių: žemès ūkị, pramonės įmones, prekybą, amatus ir tarnybą privačiose įmonèse [56]. Leidimai darbui Lietuvoje dažniausiai būdavo išduodami iki šešių mėnesių, vèliau jie galèjo būti pratęsti. Ypač daug Vokietijos piliečių inžinierių ir aukštos kvalifikacijos šaltkalvių, net bendrovès direktorių samdè Tilmansų fabrikas Kaune [25].

Lietuviams buvo gerai žinoma Vokietijos kompanija „Siemens“, kurios atstovybè Lietuvoje èmè veikti iškart po to, kai $1918 \mathrm{~m}$. buvo paskelbta respublikos nepriklausomybè. „Siemens“ atstovybė bendradarbiavo su Lietuvoje veikiančiomis ịstaigomis. Beveik visi Lietuvos fabrikai buvo aprūpinti įvairia „Siemens“ įranga. Kino filmai buvo rodomi „Siemens“ aparatūra, naudojami „Siemens" radijo ir telefono aparatai. „Siemens" atstovybèje dirbo ne tik Vokietijos piliečiai, bet ir keletas tuometinejje Lietuvoje garsių žmonių. Nuo $1921 \mathrm{~m}$. pradžios bendrovei pradejo atstovauti Vytauto Didžiojo universiteto docentas ir garsus inžinierius Aleksandras Putrimas. Jo pavaduotoju buvo Vytauto Didžiojo universiteto ir Niujorko kolegijos prof. Aleksandras Mačiūnas.

Kai kurie Vokietijos kompanijose Lietuvoje dirbę Vokietijos piliečiai be pagrindinio oficialaus darbo gamyboje vykdè ekonominę bei politinę žvalgybą Lietuvoje. Ryškiausias tokios veiklos pavyzdys yra Vokietijos pilietis fon Šamis (von Chamier). Kaip tikrosios veiklos priedangą 1924 m. Kaune jis pradejo leisti Lietuvos vokiečių Kulturverbando laikraštị Litauische Rundschau (liet. „Lietuvos apžvalga“), Kaune ịkūrẻ kooperatyvą „Centras“, įsteigè vokiečių smulkaus kredito banką, vokiečiu sandèlį, Kauno vokiečių spaustuvę (Deutsche Druckerei-Gesellschaft, Kowno), kuri ir leido minètą laikraštị. Greta spaustuvès jis turèjo 
vokiečių knygyną su kiosku [68]. Šamio veiklai specialūs bankai iš Vokietijos pervesdavo stambias pinigų sumas. Antai $1925 \mathrm{~m}$. gegužę nurodyta pervesti 7150 Lt [1].

Išaiškinus Šamio, o vẻliau ir kitų aktyvių Vokietijos rezidentų veiklą, Lietuvos saugumo organai ėmè atidžiai stebėti Vokietijos kapitalo įmonèse Lietuvoje dirbančius Vokietijos piliečius. Dalis jų, prisidengdami darbu Vokietijos verslo įmonėse, ị Lietuvą atvyko dirbti kaip Vokietijos agentai. 1934 m. dèl Klaipèdos krašto nacistų teismo paaštrẻjus Lietuvos ir Vokietijos santykiams, tautininkų spaudoje pasirodė ekonomistų publikacijų, kuriose buvo kviečiama griežčiau apriboti svetimšalių ekonominę veiklą Lietuvoje. 1938 m. pabaigoje buvo nustatyta, jog „Philips“ bendrovès atstovybeje Kaune dirbęs Herbertas Štalis (Stahl), vykdydamas politinę misiją, vadovavo slaptam 70 narių turinčiam ir nacistine ideologija besivadovaujančiam skyriui [19]. Atskleidus H. Štalio veiklą, šiam teko išvykti iš Lietuvos. Tačiau tokių atvejų Lietuvoje buvo išaiškinama gana nedaug. Daug aktyviau ir drąsiau politinėje veikloje dalyvavo Klaipėdos krašte su darbo leidimais dirbę Vokietijos piliečiai, kurie sudarè nemažą dalị visų dirbančiụjų. Dèl šios priežasties 1934 m. Lietuvos URM, Finansų ministerijos ir Lietuvos vidaus reikalų ministerijos atstovai Vokietijos piliečių atžvilgiu nusprendè laikytis šios taktikos: suvaržyti ar nebeduoti jiems naujų darbo leidimų, pasistengti iškraustyti esamus Vokietijos piliečius bei sudaryti Vokietijos piliečių tikslius sąrašus, pažymint, nuo kada dirba Lietuvoje [4]. Vis dèlto svarbiausias tokių sankcijų motyvas buvo politinis: siekta užkirsti kelią užsienio šalies piliečių dalyvavimui antivalstybinėje veikloje, o ne mažinti užsieniečių darbuotojų skaičių.

\section{PAGRINDINIS VOKIEČIŲ VERSLAS - ŽEMĖS ŪKIS}

Nors vokiečiu ịmonių veikla buvo gana sèkminga, pagrindinis Lietuvos ir Klaipèdos krašto vokiečių verslas buvo žemès ūkis. $1938 \mathrm{~m}$. balandžio $15 \mathrm{~d}$. duomenimis, Lietuvos vokiečių ùkių, be Klaipėdos krašto, buvo 2 781, o jų plotas sieké 39873 ha žemės [31]. Daugiausia vokiečiai turejjo 5-10 ha ūkius - 828 vienetai, $1-5$ ha ūkius turẻjo 763 vokiečių šeimos, 10-20 ha ūkius - 681 savininkas, 20-30 ha - 259, 30-50 ha - 161 ūkis, 50-100 ha - 61 ūkis, o 100 ha ir didesni dvarai priklausė tik 28 vokiečiams. Labiausiai vokiečių dvarai nukentèjo dèl žemės reformos, kadangi buvo atimta didesnè dalis žemės, o dvarų žemèvaldai palikta tik iki 100 ha žemès. Štai Prienų valsčiuje vokiečiui Jonui Fišeriui priklausęs Ašmenos dvaras 1926 m. nuo 260 ha buvo sumažintas iki 82 ha, Stepui Gerštarui priklausiusiam Šaltupio dvarui iš 260 ha paliko tik 81 ha, Liudui Hofmanui priklausiusio Liepoloto dvaro žemès $1928 \mathrm{~m}$. buvo apkarpytos nuo 230 ha iki 95 ha [38]. Baronai fon der Ropai (von der Ropp), keleto dvarų Radviliškio, Lygumų ir Pakruojo valsčiuose valdytojai, buvo ilgamečiai vokiškų tradicijų puoselètojai, o jaunesniosios kartos atstovai užèmè svarbias pareigas Kulturverbando valdyboje, tiesiogiai bendravo su Vokietijos institucijomis. Svarbiausias šios giminès dvaras buvo Pakruojyje. Po Pirmojo pasaulinio karo Pakruojo dvaras buvo pavyzdinis ūkis, garsėjęs pramonine gyvulininkyste. Po 1922 m. žemès reformos Ropų ūkis sumažejjo: jiems buvo paliktas dvaro centras ir 300 ha žemès. Dvare buvo atlikta melioracija, toliau plètojama gyvulininkystè, sodininkystè, bitininkystė. 1940 m. dvarą pagal testamentą paveldejo Julius Ropas, jame buvo įkurdintas vokiečių repatriacijos štabas. Kulturverbandui vadovavo ilgametis jo pirmininkas stambus žemvaldys Oskaras fon Reichardas, Radviliškio valsčiuje valdęs Daugelaičių dvarą. Vokiečių kilmės grafams Pliateriams (Plater) priklausė Antazavès dvaras Zarasų rajone, tačiau $1923 \mathrm{~m}$. Antazavės apylinkèse, išdalijus iš dvaro paimtą žemę savanoriams ir bežemiams, dvarui liko 160 ha žemės. Pliaterių šeimai priklausẻ Vilkènų dvaras, tačiau svarbiausias jų dvaras buvo Švėkšnoje. Joniškio rajone esan- 
tis Jakiškių dvaras priklausė vokiečiui Koškoliui, o Medvilionių dvaras - fon Gesų (Göss) šeimai. Labai turtinga ir žymi buvo fon Grotuso (Grotthuss) giminè, kurios didelè dalis turto buvo Latvijoje. Joniškio rajone dvarininkams Grotusams priklausè Kaucmanès dvaras. Didelè dalis vokiečių dvarų buvo sunaikinta Antrojo pasaulinio karo pabaigoje bei sovietmečiu.

Vokiečių ūkininkai gyveno pietvakarinèje Lietuvos dalyje, kuri pasižymėjo derlingiausiu dirvožemiu. Daugiausia vokiečių ūkininkų buvo Vilkaviškio apskrityje - 1111 ūkių su 13485 ha žemès, arba 40 \% visų vokiečių ūkių, antroje vietoje - Šakių apskritis, kurioje buvo 720 vokiečių ūkių su 10294 ha žemès. Tauragès apskrityje buvo 454 ùkiai su 4793 ha žemès, o Marijampolèje dar mažiau - 223 ūkiai su 2616 ha žemès. Vos po keletą vokiečių ūkininkų aptinkame tik Kauno, Zarasų, Telšių, Rokiškio, Panevėžio, Alytaus, Biržų, Kèdainių apskrityse [31].

Kur kas geresnes pozicijas žemės ūkyje vokiečiai užèmė Klaipėdos krašte; čia jie valdè 42,6 \% visų krašto žemès ūkio naudmenų. Klaipèdos krašte iš 141 dvaro vokiečių dvarininkams priklause 86, arba $61 \%$, su 21 102,4 ha žemès [85]. Klaipėdos krašte vokiečių dvarininkų padètis taip pat buvo daug geresnè, kadangi čia nebuvo vykdoma žemès reforma, todèl visi dvarai liko nesumažinti. Pažymėtina, jog Klaipėdos krašto vokiečiai ūkininkai ekonomiškai buvo kur kas veiklesni ir savo verslo reikalus tvarkẻ bendrai susibūrę ì nedideles Žemės ūkio draugijas (Landwirtschaft Ortsverein), kurios turejo 2415 narius [32]. Visose Klaipėdos krašto apskrityse veikè ịvairios vokiečių ekonominės organizacijos, vienijusios namų savininkus, gyvulių, triušių ir paukščių augintojus, bitininkus, pienininkus ir žvejus. Vien tik Pagėgių apskrityje veikusi Bitininkų draugija (Biehenzuchtverein) turejo 40 narių, Paukštininkų draugija (Gefliegel und Taubenzuchtverein) - 80 narių, Namų savininkų draugija (Haus und Grundbesitzverein) - 70, Mažų gyvulių augintojų draugija (Kleintierzuchtverein) - 50, Augintojų klubas (Klub der Zuchter) - 30, Triušių augintojų draugija (Kaninchen Zuchtverein) - 30, Pienininkų draugija (Molkereigenossenschftverein) - 300, Klaipėdos paukštininkų sąjunga (Memel Gefluegel Zuchtbund) - 20, Gyvulių augintojų bendrija (Viehverwertungsgenossenschaft) Luksargiuose - 150 narių [32]. Lietuvoje vokiečių ūkininkų draugijų nebuvo ịkurta net ir gausiau vokiečių apgyvendintose apskrityse. Veikiausiai Lietuvos vokiečių ūkininkams tokios draugijos nebuvo būtinos, kadangi jos menkai būtų padejusios konkuruoti žemès ūkio rinkoje. Tuo tarpu Klaipėdos krašte priklausymas panašioms draugijoms ūkininkams garantavo galimybę parduoti produkciją geresne kaina.

Lietuvos vokiečių dvarininkų bei stambesnių ūkininkų politinė veikla suaktyvėjo nuo 4-ojo dešimtmečio vidurio, kada iš Vokietijos gaunamos paramos dali Kulturverbandas èmè skirti vokiečių ūkininkų problemoms spręsti. Tuo metu prie kiekvieno Kulturverbando skyriaus (kurių iš viso Lietuvoje veikè $24-I$. J.) buvo nutarta steigti specialias ūkininkų sekcijas, kurios turejo padèti ne tik ūkiams sustiprèti ekonomine prasme, bet ir stiprinti vokiškumą. Ūkininkų klausimams spręsti buvo pasamdyti du žemès ūkio patarèjai [10]. Kulturverbandas ūkiniams vokiečių reikalams lěšas gaudavo iš Vokietijos specialaus fondo (Landwirtschaftsbund der NSDAP), kuris rūpinosi užsienyje gyvenančių vokiečių ūkių išlaikymu. Kulturverbando pirmininkas O. Reichardas ūkininkų reikalams smulkesnes pinigų sumas gaudavo ir iš vokiečių pasiuntinybès Kaune, pvz., 1937 m. gruodị iš gautų 12 tūkst. Lt buvo paimta 5 tūkst. Lt vokiečiams ūkininkams paremti [12]. Kaip ir Klaipėdos krašte, skirstant gautus iš Vokietijos įstaigu pinigus, teikiant pašalpas ir beprocentines paskolas buvo atsižvelgiama ị ūkininkų patriotiškumą ir nuopelnus vokiškumui [11]. Minèti kriterijai 
bei ūkininkų ekonominè padètis buvo kruopščiai ištiriama ir pranešama O. Reichardui. Pastarasis slaptumo sumetimais per patikimus asmenis nurodydavo Kulturverbando skyrių vadovybei, kuriuos asmenis galima paremti finansiškai. Visų pirma buvo sušelpiami tie ūkininkai, kurie turëjo skolų lietuvių bankuose ir buvo nukentėję dèl bankrutavusių vokiečių bankelių. Antai 1937 m. gruodžio mėnesị Kulturverbandas padejo, kad aktyvistų brolių Valinskių ūkis, esantis Šakių apskrityje, Starkų kaime, „neprieitų iki varžytinių“[12]. Nors Kulturverbando vadovybè labai džiaugèsi parama iš Vokietijos, tačiau Vokietijos finansinès injekcijos Klaipėdos krašto vokiečių ūkiams buvo daug didesnès, kadangi tai buvo susiję su jos ilgalaikiais politiniais interesais krašte.

Ketvirtojo dešimtmečio viduryje Vokietija, Klaipedos krašte vykdydama didelio masto ekonomines operacijas, rèmė vietinius vokiečių ūkininkus. Štai 1936 m. balandžio $21 \mathrm{~d}$. Vokietijos URM pranešè, kad A. Hitleris leido skirti 1 mln. reichsmarkių (toliau RM) kiaulių ir galvijų supirkimui Klaipėdos krašte [7]. 1936 m. pavasarị Klaipėdos Direktorijos pirmininkas Augustas Baldžius, tarpininkaujant Rytprūsių gauleiteriui Erichui Kochui, susitarè su Vokietijos ūkio ministru J. Šachtu (Schacht) dèl kiaulių supirkimo iš mažažemių ir smulkiųų ūkininkų [9]. Visa operacija turejo būti vykdoma ypač slaptai, per patikimus asmenis, kad informacija nepatektų i viešumą. Lietuvos vokiečių dvarininkų finansinè padètis bei gaunama parama iš Vokietijos buvo kur kas menkesnè nei Klaipėdos krašto vokiečių dvarininkų. Džeimsas Guba (Gubba), valdęs 355 ha dydžio Gedmino dvarą, Henrikas Konradas (Conrad) - Sendvarị su 510 ha ir Konradas fon Dresleris (von Dressler) - Šereitlaukio dvarą su 1783 ha žemès [85] buvo aktyviausi vokiečių dvarininkai Klaipėdos krašte. Klaipedos krašto 48 dvarininkai per slaptas Vokietijos kredito bendroves iki $1934 \mathrm{~m}$. buvo gavę $4 \mathrm{mln}$. Lt finansinès paramos. Iš jų vien tik K. Dresleris gavo 443 484, H. Konradas - 66 tūkst., Dž. Guba - 67 tūkst. RM paskolų [29]. Ši finansinè parama buvo skiriama už ypatingus nuopelnus vokiškumui bei uolų darbą Vokietijos labui. Tačiau net ir už uoliausią tarnybą Reichui Lietuvos dvarininkai negalejo tikètis panašių kreditų, kadangi Vokietijos interesai Lietuvoje buvo daug mažesni nei Klaipedos krašte, kurị Vokietija siekè susigrąžinti kaip Versalio sutartimi sąungininkų atimtą teritoriją.

\section{VOKIEČIŲ EKONOMINÉS VEIKLOS POKYČIAI 4-AJAME DEŠIMTMETYJE}

Iki 1930 m. Lietuvos miestuose gyveno 20 \% gyventojų (tuo metu Latvijoje - 30 \%, Rytu Prūsijoje - 46 \%). Daugelyje miestų centrų buvo įsikūrę kitataučiai verslininkai, ypač prekybininkai. Lietuviams buvo sunku ịsitvirtinti versle. Nuo 4-ojo dešimtmečio pradžios sustiprèjo lietuvių veržimasis ị pramonę ir prekybą, ịsikūrè stambios pusiau valstybinèskooperatinès bendrovès, ịsteigta „Verslininkų sąunga“, kuri visaip skatino ir rẻmé lietuvius verslininkus. Ekonominès krizės metais Lietuvoje, kaip ir kitose Europos šalyse, vis garsiau buvo skelbiami nacionalinès ekonomikos šūkiai, kurie kvietė lietuvinti Lietuvos pramonę ir prekybą. Stiprèjantis lietuvių nacionalizmas, sunkūs 1929 m. pasaulinės ekonominès krizès padariniai, kaimo gyventojų darbo paieškos miestuose ir lietuvių veržimasis ị su žemès ùkiu nesusijusias ekonomikos šakas sudare didelę konkurenciją tautinių mažumų verslo atstovams. Lietuvos vyriausybè skatino verslo lietuvinimą ne tik proteguodama lietuvius verslininkus, bet ir valstybès lèšmis steigdama bankus, prekybos ir pramonès įmones: iki $1938 \mathrm{~m}$. investicijoms ị naujas akcines bendroves buvo išleista $116 \mathrm{mln}$. Lt [83]. Nuo 1934 m. Vokietijoje prasidejjus antisemitinėms akcijoms, Lietuvos vokiečiai pajuto žydų įmonių savininkų boikotą. Tik nedidelè dalis žydų ir toliau savo įmonèse samdè vokiečių darbuotojus, didesnè dalis vokiečius atleido iš darbo [6]. 
1934 m. vasarị uždarius Klaipėdos krašte veikusias vokiečių nacistines partijas, lietuvių visuomenejje kilo didelis nepasitenkinimas vokiečių ardomąja veikla. Šešèlis krito ir ant beveik jokių ryšių su Klaipedos krašto vokiečiais neturinčių Lietuvos vokiečių. Tautininkų spaudoje lietuviai buvo kviečiami vienytis kovai prieš vokiečius: „Mes visi jaučiame, kad vokiečių pavojus mums didelis. Ekonominė ir politinè represija kasdien didejja. Reikalinga visos tautos ir vyriausybès skubi ir griežta kova vokietybès plètotès kelius Lietuvoje užkirsti. Ta tauta stipri ir atspari, kuri homogeninè, - švari, be priemaišų. Atsiminkim, kad visi vokiečiai Lietuvoje yra mūsu nepriklausomybès priešai ir visi jie laukia antros okupacijos (išskirta kursyvu - I. J.) [65].

Nuo 1934 m. pradžios vokiečiai Klaipedos krašte taip pat pajuto ne tik griežtesnes politines sankcijas, bet ir stiprẻjančią konkurenciją versle, kadangi $\mathfrak{i}$ ūkị vis atkakliau veržèsi Lietuvos valstybinio ir privataus kapitalo įmonès, iniciatyvą steigti naujas bendroves rodè žydai. Tačiau Klaipèdos krašto vokiečiai dèl savo pablogèjusios ekonominès padèties visada galèjo tikètis pagalbos iš Vokietijos užsienio reikalų ministerijos bei kitų institucijų. Kita vokiečiams palanki aplinkybė buvo ta, kad Klaipėdos krašto vokiečius gelbejo didelè Vokietijos rinka, todèl stambesnès įmonès visiškai nesibodejjo brangiau parduoti produkciją lietuviškoms ịmonèms nei Vokietijos ir vietinėms ịmonėms. P. Žostautaitės teigimu, Klaipėdos pramonininkai bei prekybininkai sąmoningai ignoravo Lietuvos vidaus rinką, nors trečdalis pramonès produkcijos (popierius, vinys, muilas ir kt.) buvo parduodama čia [85].

Ketvirtojo dešimtmečio viduryje Lietuvos tautinių mažumų verslui ėmé trukdyti gana stipriai išplètota ekonominè propaganda, kuria siekta sustiprinti lietuvių pozicijas versle. Buvo skelbiama, kad reikalinga ne tik gera ūkio, bet ir tautinè ūkio politika. Tautinè politika turejo remti lietuvių verslo iniciatyvas, netgi proteguoti lietuvių įmones („šioje kovoje lietuvis turi būti paremtas"). Kaip sektinas pavyzdys nurodoma kaimyninė Latvija, kuri nepabijojo atimti šimtmetinių privilegijų iš vokiečių mažumos ir vieną po kitos perimti vokiškas imones [66]. Latvijos ekonominė politika buvo giriama, nes čia 1936 m. kitataučiai versle sudarè tik $20 \%$, nors dar prieš keletą metų jie valde $90 \%$ visų verslo i̇monių. Pavyzdiniu buvo laikomas ir naujasis Latvijos prekybos įstatymas, pagal kurị Prekybos rūmuose dirbo 135 nariai, iš kurių tik aštuoni žydai ir 13 vokiečių [48]. 1935 m. Verslo leidinyje gana tiesmukai buvo aiškinamos lietuvių atsilikimo versle priežastys: pagrindinè atsilikimo priežastis yra ta, kad lietuviai Lietuvos versle tesudaro $33 \%$, o žydai - 50 \%. Leidinyje autoriai gana atvirai piktinosi, kad kitataučiai Lietuvos ūkyje yra užèmę pelningiausias vietas [46]. Iš tiesų labai reikšminga verslo subjektų dalis priklausẻ žydams. $1936 \mathrm{~m}$. Lietuvoje veikè 6750 lietuvių įmonių, turinčių 21 tūkst. darbuotojų, 4850 žydų įmonių su 16 tūkst. darbininkų, 600 kitų tautybių asmenų įmonių su 2 tūkst. darbuotojų, iš jų 15 užsienio piliečių su 550 darbuotojais [62]. Remdamiesi tokia statistika, verslo lietuvinimo iniciatoriai skelbè išvadą, kad lietuvių tolerancija yra kenksminga patiems lietuviams [66], kad kantrybė ir nuolaidumas lietuviams daro gèdą ir silpnina jų padėtį užimtose pozicijose. Buvo kviečiama ugdyti tautoje „ekspresingaji veiklumą“ siekiant savo tautos ir valstybės interesų [39].

Ypač nepalankiai Lietuvos verslo aplinka reagavo ị vokiečius po 1935 m. kovo mèn. kilusio ažiotažo paskelbus nuosprendi Klaipėdos krašto nacistinių partijų nariams Noimano (Neumann) ir Zaso (Sass) teismo procese. Tuomet lietuvių visuomeneje kilo nemažas pasipiktinimas vokiečių išdavikiška veikla ir ryšiais su Vokietija, susiformavo ypač neigiamas požiūris ị vokiečius. Lietuvių patriotinèje spaudoje buvo pasmerkti ne tik advokatai, gynę kaltinamuosius šioje byloje, kilo nepasitenkinimas visa vokiečių bendruomene, jos dalyvavimu visuomeniniame bei ekonominiame šalies gyvenime [44, 60, 64]. Agituota nepirkti 
vokiškų prekių $[43,45,61]$. Spaudoje atvirai piktintasi vokiečių kompanijų parduotuvėmis bei vokišku prekių prekyba, pvz., Vokietijos avalynès firmos „Salamander“ ir "Mercedes“ parduotuvèmis Kaune [40]. Pasirodè keletas publikacijų apie apsinuodijimus vokiškais vaistais, kurie buvo pirkti vokiečių vaistinèse [41]. Buvo piktinamasi vokiškų filmų repertuaru Lietuvos kino teatruose [37].

Dèl vis prastėjančių vokiečių ir apskritai kitataučių verslo sąlygų Lietuvoje, Kulturverbando centro valdybos iniciatyva $1937 \mathrm{~m}$. gruodžio 12 d. Kaune, vokiečių gimnazijoje, ìvyko vokiečių amatininkų suvažiavimas. Susirinkimo metu Richardas Kosmanas (Kosmann) išsakè pasipiktinimą, kad neseniai ịsteigti Lietuvos Prekybos, pramonès ir amatų rūmai nebendradarbiauja su vokiečių amatininkais, kurie pirmieji ị Lietuvą atnešè amatus. Kitas ilgametis Kultuverbando aktyvistas Konstantinas Cerpinskis, susirinkime pateikęs trumpą istorinę apžvalgą apie amatų reikšmę vokiečiams ir Lietuvai, pabrèžè, kad nors Kaunas buvęs vokiečių amatininkų miestas, tačiau maždaug nuo $1840 \mathrm{~m}$. vokiečius amatininkus iš savo pozicijų stūmé lenkai, žydai, rusai. Pasak K. Cerpinskio, vokiečių amatininkų silpnumo priežastis buvo amatininkų vienybės trūkumas, juos vienijančios sąjungos nebuvimas. Šio susirinkimo metu buvo patarta vokiečių verslininkams skaityti specialią spaudą ir vesti buhalteriją [10].

Iš tiesų vokiečių verslininkams, kaip ir ūkininkams, trūko vienybės. Kita vertus, jie buvo gerai integravęsi ị miestų ir miestelių gyvenimą, pritapę prie lietuviškos aplinkos, todèl sąmoningai vengė pabrèžti savo kitoniškumą. Vokiečiai ekonominiuose santykiuose labiau orientavosi ị lietuvius, o žydams, kurie sudarẻ konkurenciją versle, minètame suvažiavime buvo paskelbta kova. Pažymėtina, kad vokiečių amatininkų konkurencija su žydais kilo ne dèl antisemitizmo, bet dèl ekonominių interesų. Minètas vokiečių amatininkų suvažiavimas yra reikšmingas dèl sprendimo susivienyti ir aktyviau ginti savo interesus. Suvažiavimas išrinko komisiją, kuri nuo šiol turèjo pasirūpinti vokiečių verslo reikalais [10].

Iš Lietuvos saugumo tarnybų mėnesinių apžvalgų galima spręsti, kad $1938 \mathrm{~m}$. vokiečiai daug aktyviau rūpinosi savo verslo reikalais, o Kulturverbando instruktorių konsultacijų bei iš Vokietijos gaunamos paramos dẻka buvo ịsteigtos dešimtys naujų įmonių. Kulturverbandas tapo ne tik už vokiečių kultūrą, bet ir už ekonominę veiklą atsakinga organizacija. Minètais verslo reikalų instruktoriais tapo devyni jauni ir aktyvūs Kulturverbando nariai, kurie 1937 m. buvo išsiųsti ị Vokietiją lankyti žemės ūkio kursų. Lietuvos saugumo pareigūnai įtarè, kad greta žemès ūkio paskaitų šie asmenys galejjo išklausyti ir nacionalsocialistų mokyklos kursą, todèl jų veikla buvo stebima [15]. Lietuvos saugumo pareigūnų ataskaitose nurodoma, kad Kulturverbando instruktoriai, važinėdami po provincijos skyrius, teikè pagalbą tautiečiams ne tik įsteigiant naujas įmones, bet ir patardami, kaip su valdybos žinia gauti paskolas iš Vokietijos verslui plètoti [17]. $1938 \mathrm{~m}$. pradžioje aktyviai skatinamas vokiečių verslas davè vaisių. Verslininkai ėmé planuoti kontaktus su partneriais Vokietijoje. 1938 m. birželi Lietuvos vokiečių atstovai dalyvavo Vokietijoje vykusiose amatų dienose [16].

Antrasis Vokiečių amatininkų atstovų susirinkimas buvo sušauktas $1939 \mathrm{~m}$. kovo 5 dieną. Jo metu nutarta parengti verslo žinovus, šiandien vadinamus vadybininkais, kurie galètų vadybos žinias perteikti kitiems. Tam tikslui ị Vokietiją buvo išsiųsta 14 jaunųjų verslininkų [19]. Susirinkimo metu kalbèta apie Lietuvos vokiečių amatininkų fondą, tačiau vèliau ši idejja liko neišplètota. 1940 m. vasarị Kaune ịvykusio Kulturverbando suvažiavimo metu buvo išrinkta nauja valdyba ir ịtrauktos naujos pareigybès, susijusios su vokiečių ekonomine plètra: Teodoras fon der Rekè (von der Recke) buvo išrinktas ūkininkų, arba žemès ùkio sekcijos, vadovu, R. Šveiceris - amatininkų, A. Hofmanas - kaimynystès sekcijos 
vadovu [22]. Apie vokiečių i̇monių sẻkmingą darbą ir plètrą 4-ojo dešimtmečio pabaigoje galime spręsti iš išaugusio vokiečių įmonių skaičiaus: $1934 \mathrm{~m}$. veike 148 vokiečių įmonès, 1938 m. - 255, o 1940 m. pradžioje - 331 vokiečiu ịmonè.

\section{VOKIEČIU EKONOMINĖS VEIKLOS LIETUVOJE PABAIGA}

1938-1939 m. brandinti verslo planai, siekiant pagerinti savo ekonomines pozicijas Lietuvoje, buvo igyvendinti tik iš dalies. Tą padaryti vokiečių bendruomenei sukliudè A. Hitlerio 1939 m. spalio 6 d. paskelbtas sprendimas iškeldinti Baltijos šalių vokiečius. Nuo 1939 m. pabaigos Kulturverbando valdyba buvo įtraukta ị Vokietijos organizuotos vokiečių iškeldinimo iš Lietuvos operacijos vykdymą. Buvo pareikalauta kruopščiai suregistruoti visus vokiečių tautybės asmenis bei jų valdomą turtą. $1940 \mathrm{~m}$. pavasarị vokiečių įmonių darbas labai pablogejo arba visai sustojo - visa Lietuvos vokiečių bendruomenė èmè rengtis išvykimui ị Vokietiją. Vokiečių ūkininkai ir verslininkai 1940 m. patyrẻ daug nuostolių, kadangi su iškeldinimu susiję darbai vyko permainingai. Toki nepastovumą nulėmė politinès permainos. 1940 m. birželio 15 d. Lietuvą okupavus SSRS, Vokietija tautiečių iškeldinimo klausimu turèjo vesti derybas su SSRS. Berlynas tai įsakydavo Kulturverbandui kuo skubiau ruoštis iškeldinimui, tai po kurio laiko atšaukdavo nurodymus ir liepdavo laukti [23]. Tikėdamiesi išvykti 1940 m. pradžioje vokiečiai uždarè įmones, paskubomis išpardavè gyvulius, ūkio padargus, neapsirūpino kuru, maisto atsargomis, sodybose iškirto vaismedžius [24]. 1940 m. vasarą po SSRS okupacijos Lietuvos vokiečiai pajuto Sovietų valdžios sankcijas: buvo nusavinti dvarai, dalis ūkininkų žemès, atimta daug privataus turto (arklių, žemès ūkio padargų, baldų). Vokiečiai jautėsi apgauti ir dèl to kaltino Kulturverbando vadus, nes už parduotą turtą gautus pinigus jie išleido avalynès, kostiumų, patalynès pirkimui, t. y. toms prekèms, kurias Kulturverbando agitatoriai rekomendavo įsigyti [24]. Vokiečiu bendruomenei buvo skaudu susitaikyti su mintimi, kad reikès palikti ilgai kurtą gyvenimą ir kauptą turtą.

Rengiantis vokiečių iškeldinimui iš Lietuvos buvo kruopščiai suregistruotas visas Lietuvoje paliekamas vokiečių turtas. Ši statistika vertinga ir tuo, kad tiksliai buvo nustatyta paliekamo turto vertè. Už vokiečių registraciją ir iškeldinimą atsakinga Etninių vokiečių aprūpinimo tarnyba (Volksdeutche Mittelstelle - VoMi) buvo ịpareigota suregistruoti Lietuvos vokiečių valdytą turtą. Kadangi Vokietija žadèjo išmokèti kompensacijas už vokiečių Lietuvoje paliekamą turtą, buvo būtina ji tiksliai įvertinti. Vokiečių turto surašymui buvo paskirti atsakingi asmenys: už žemės ūkio paskirties turto surašymą atsakingas buvo fon der Grotusas, už amatininkų dirbtuvių turtą -Hiolcermanas (Hölzermann), už prekybos įmones - Hesas (Hess) ir Vogelis, už namų savininkų turtą - Gutčè (Gudsche) ir Giunteris (Günther) [80]. 1940 m. sausị pagal surinktus duomenis Kulturverbandas vokiečių turtą ịvertino $100 \mathrm{mln}$. Lt [23]. $1940 \mathrm{~m}$. liepos mènesio duomenimis, Lietuvos vokiečiai valdè 198 gamyklas, dirbtuves ir fabrikus, kurių vertè siekè $10 \mathrm{mln}$. 272502 Lt. Vokiečių valdyti 76 malūnai buvo ịvertinti $4 \mathrm{mln}$. $933745 \mathrm{Lt}, 36$ šaltkalvių dirbtuvès - $871432 \mathrm{Lt}$, mésos ir sūrio gamyklos - $351350 \mathrm{Lt}, 17$ smulkių dirbtuvių - 1 mln. 159175 Lt, keturi metalo fabrikai - 599 tūkst. Lt [69]. P. Arlauskas statistiką papildo vokiečių palikto žemès ūkio paskirties turto duomenimis. Jis teigia, kad iš Lietuvos išvykus 5156 ūkių savininkams ir jų šeimų nariams, liko 67024 ha žemès, 5541 gyvenamųjų ir 13876 ūkinių pastatų, 4826 arkliai, 8050 galvijų, 4629 kiaulès, nemažai kito turto [70]. Remiantis V. Venskūno duomenimis, išvykę vokiečiai Lietuvoje paliko 90880 ha valdytos žemès ir turto iš viso už 211 mln. 220 tūkst. 53 RM [84]. V. Venskūno duomenys beveik sutampa su Aleksandro 
de la Krua (A. de la Croix) iškeldintų Lietuvos vokiečių turto registru. A. de la Krua apskaičiavo, kad Lietuvoje vokiečių palikto turto bendra vertẻ siekẻ $210 \mathrm{mln}$. 965 tūkst. 995 RM [71] (2 lentelè).

2 Ientelè. Iškeldinimo komisijai pateikti duomenys apie vokiečių paliktą nuosavybę Lietuvoje iškeldinimo metu $1941 \mathrm{~m}$.

\begin{tabular}{|c|c|c|}
\hline Nuosavybės rūšis & Vertè RM & Procentai \\
\hline Žemès sklypai & $35 \mathrm{mln} .151061 \mathrm{RM}$ & $16,7 \%$ \\
\hline Žemès ūkio paskirties žemè & $147 \mathrm{mln} .889650 \mathrm{RM}$ & $70 \%$ \\
\hline Amatininkų dirbtuvės & 13 mln. 252543 RM & $6,3 \%$ \\
\hline Namai & $1 \mathrm{mln} .179631,50 \mathrm{RM}$ & $0,6 \%$ \\
\hline Indèliai bankuose & $1 \mathrm{mln} .910971 \mathrm{RM}$ & $0,9 \%$ \\
\hline Hipotekos & $278829 \mathrm{RM}$ & $0,1 \%$ \\
\hline Vertybiniai popieriai & $850597 \mathrm{RM}$ & $0,4 \%$ \\
\hline Kitas turtas & 4 mln. 118319 RM & $2 \%$ \\
\hline Skolos & 6 mln. 334392 RM & $3 \%$ \\
\hline Bendra vertè RM & 210965995,21 RM & $100 \%$ \\
\hline
\end{tabular}

Šaltinis: Croix de la A. Die Umsiedlung im Spiegel der Zahlen. Heimatgruss, 1961, S. 58-59.

Iš Lietuvos 1941 m. išvyko daugiau nei 50 tūkst. vokiečių, tarp jų ir keli tūkstančiai lietuvių. Kulturverbando nariais tapo ir iki tol nedalyvavę šios organizacijos veikloje, Lietuvai visą laiką lojalumą rodę vokiečiai, buvę valstybẻs ir visuomeninių įstaigų tarnautojai.

Su vokiečių iškeldinimu baigèsi vokiečių ūkinès veiklos Lietuvoje istorija, tačiau ji vèl atgijo 1942-1944 m., kai ị Reicho okupuotą Lietuvą didelè dalis buvusių Lietuvos vokiečių sugrịžo kaip kolonistai. Norą grị̌zi atgal ị Lietuvą tarp vokiečių sustiprino ne tik patirti buitiniai nepatogumai persikèlèlių stovyklose, bet ir gimtinès ilgesys. Ši kartą kolonistai apsigyveno ir dirbo geriausiuose Lietuvos ūkiuose, be konkurencijos vadovavo daugumai imonių, jautėsi tikraisiais krašto šeimininkais.

\section{IŠVADOS}

Apibendrindami Lietuvos vokiečių ekonominę veiklą Lietuvoje galime teigti, kad XX a. 3-iajame dešimtmetyje verslą jie plètojo savarankiškai, gaudami paramą tik iš tautinès bendruomenès narių, todèl vokiečių ūkiniai laimèjimai buvo gana kuklūs. Vokiečiai nepuoselejo didesnių verslo ambicijų, kadangi didžiausia bendruomenės dalis vertèsi žemès ùkiu ar smulkiu verslu. Trečiajame dešimtmetyje vokiečiams priklausẻ tik keliolika stambių immonių bei 28 dvarai. Vokiečių verslo i̇monių veikla nebuvo sutelkta keliose srityse, kaip tai buvo būdinga Klaipèdos kraštui, kur vokiečiai vyravo medžio apdirbimo, chemijos, metalo ir statybos pramonejje. Lietuvos vokiečiai pagal išduotas verslo licenzijas verslą plètojo labai ivvairiose srityse, niekur neturèjo monopolio teisių, turejjo savarankiškai atlaikyti konkurenciją. Iki $1934 \mathrm{~m}$. verslo aplinka vokiečių atžvilgiu buvo pakankamai palanki. Smarkesnị spaudimą vokiečiai patyrè tik 1934-1935 m. kilus ažiotažui dèl Klaipėdos krašto vokiečių nacistų teismo bei sustiprejjus lietuvių patriotų akcijai lietuvinti šalies ekonomiką. Su panašiu lietuvių spaudimu versle susidūrè ir žydai.

Lietuvos vokiečių vaidmuo respublikos ekonominiame gyvenime tapo ryškesnis nuo 4-ojo dešimtmečio vidurio, kada iš Vokietijos jie èmé gauti solidesnę finansinę paramą ùkinei veiklai. Tuomet padidèjo vokiečių įmonių skaičius, išaugo vokiečių valdomos 
nuosavybės vertè. Šiems ūkio laimėjimams didelę reikšmę turẻjo vokiečių Kulturverbando valdybos sprendimai aktyvinti bendruomenès ūkinę veiklą, dalytis vadybos žiniomis, siųsti jaunimą gilinti verslo ir žemės ūkio vadybos žinių i t Vokietiją bei ieškoti paramos verslui specialiuose Vokietijos fonduose. Tačiau Kulturverbandas netapo stipriu vokiečių ekonominio gyvenimo koordinatoriumi, jo parama vokiečių ūkininkams ir verslininkams buvo epizodiška ir nevaidino lemiamo vaidmens.

Palyginti su Klaipėdos krašto vokiečių ekonomine padètimi, Lietuvos vokiečiai niekada neužèmé vyraujančios padèties versle, jiems teikiama finansinė Vokietijos parama buvo nedidelè, tik keletas stambiausių Lietuvos vokiečių įmonių turẻjo tiesioginius prekybos ryšius su Vokietija. I Klaipėdos krašto vokiečių ūkini gyvenimą Vokietija kišosi nuo pat 3-iojo dešimtmečio vidurio, darydama spaudimą Lietuvos vyriausybei ar teikdama ịvairias subsidijas, tuo tarpu Lietuvos vokiečių ekonominè padètis Vokietijai tapo svarbi tik 4-ojo dešimtmečio pabaigoje. Nors 4-ojo dešimtmečio pabaigoje pasiekta gerų rezultatų stiprinant savo pozicijas šalies ekonomikoje, vokiečių ūkinę veiklą nutraukè Vokietijos sprendimas juos iškeldinti iš Lietuvos.

Gauta 20110213

Priimta 20111229

\section{Šaltiniai ir literatūra}

[1] 19250515 Paul Rümmler raštas Berlyno burmistrui Winkleriui. Lietuvos centrinis valstybes archyvas (toliau - LCVA), f. 923, ap. 1, b. 848, 1. 164-165.

[2] 19250522 Kauno miesto mokesčių inspekcijos raštas mokesčių departamentui Nr. 18437. Kauno apskrities archyvas (toliau - KAA), f. 209, ap. 5, b. 849, 1. 3.

[3] 1931 m. organizacijose dalyvaujančių narių skaičius tautybėmis. LCVA, f. 394, ap. 4, b. 278, 1. 17 .

[4] 19340723 tarpžinybinio posėdžio pro memoria. LCVA, f. 923, ap. 1, b. 798, 1. 35.

[5] 19340809 d. mokesčių departamento nutarimas. KAA, f. 209, ap. 2, b. 8796, 1. 14-18.

[6] 19340723 d. Kauno VSP vado V. Kymanto raportas Kauno apygardos VSP viršininkui. LCVA, f. 378 , ap. 12 , b. $159,1.5$.

[7] 19360212 Vokietijos URM valstybès sekretoriaus Bülowo slaptas raštas Reicho ūkio ministrui Schachtui. Akten zur deutschen Auswärtigen Politik 1918-1945 (toliau - ADAP), Götingen, 1973, Serie C, Band IV, 2, Nr. 554, S. 1098-1099.

[8] 19360409 agentūrinis pranešimas. LCVA, f. 378, ap. 10, b. 57, 1. 160.

[9] $1936 \mathrm{~m}$. vasario $12 \mathrm{~d}$. Vokietijos URM valstybès sekretoriaus Bülowo slaptas raštas Reicho ūkio ministrui Schachtui. ADAP, Serie C, Band IV, 2, Nr. 554, S. 1098-1099.

[10] 19371213 d. raportas VSP Kauno apygardos viršininkui. LCVA, f. 378, ap. 5, b. 3128, 1. 395398.

[11] 1937 m. gruodžio mèn. Valstybès saugumo departamento biuletenis Nr. 130. LCVA, f. 378, ap. 10, b. 186, 1. 190.

[12] 1937 m. gruodžio mèn. Valstybès saugumo policijos Kauno apygardos apžvalga. LCVA, f. 378, ap. 5 , b. $3128,1.458-459$.

[13] 1937 m. Tillmans AB pareiškimas apie veikimą. KAA, f. 209, ap. 5, b. 849, 1. 36.

[14] $19370114 \mathrm{AB}$ „Metalas“ darbuotojų sąrašas. KAA, f. 115, ap. 1, b. 14, 1. 3.

[15] 19380406 VSD direktoriaus slaptas ịsakymas Nr. 11. LCVA, f. 378, ap. 10, b. 57, 1. 315.

[16] 1938 m. liepos mèn. VSD Marijampolès apygardos apžvalga. LCVA, f. 378, ap. 5, b. 3381, 1.184.

[17] 1938 m. spalio mèn. VSD Marijampolès apygardos apžvalga. LCVA, f. 378, ap. 5, b. 3381, 1. 424 . 
[18] 1938 m. žinios apie Lietuvos vokiečių prekybos, pramonès ir verslo įmones. LCVA, f. 378, ap. 10, b. 159, 1. 7.

[19] 19390319 VSD biuletenis Nr. 69. LCVA, f. 378, ap. 10, t. 1, b. 186, 1. 266.

[20] 1939 m. Tillmans AB pareiškimas apie veikimą. KAA, f. 209, ap. 5, b. 850, 1. 128.

[21] 1939 m. Valstybès saugumo departamento biuletenis Nr. 54. LCVA, f. 378, ap. 10, b. 186, 1. 208.

[22] 19400222 Valstybès Saugumo policijos agentūrinis pranešimas. LCVA, f. 378, ap. 5, b. 3702, 1. 224.

[23] 1940 m. VSD biuleteniai. LCVA, f. 378, ap. 10, b. 225, 1. 26-293.

[24] $1940 \mathrm{~m}$. VSD Kriminalinès policijos Marijampoles apygardos biuleteniai. LCVA, f. 378, ap. 10, b. $611,1.72-96$.

[25] Br. Tilmanns ir ko“ geležies ir plieno apdirbimo akcinès bendrovès dirbančiųjų sąrašai 19341937 m. KAA, f. 209, ap. 5, b. 563, 1. 2-43.

[26] Dèl ko bankrutavo vokiečių bankas Kaune? Verslas, 1933 balandžio 13, Nr. 15, p. 4.

[27] Iškarpos iš Vokietijos laikraščių. LCVA, f. 383, ap. 7, b. 1755, 1. 231.

[28] Kauno miesto mokesčių inspekcijos darbų byla. KAA, f. 209, ap. 2, b. 8791, 1. 2.

[29] Kreditverbando ir Agrarios kreditus gavusių asmenų sąrašas. LCVA, f. 377, ap. 9, b. 117, 1. 6061.

[30] Lietuvos vokiečių prekybos, pramonès, verslo ịmonių ir žemès ūkių aprašymas. LCVA, f. 378, ap. 10, b. 159, 1. 10-13.

[31] Lietuvos vokiečių ūkiai pagal jų didumą. LCVA, f. 378, ap. 10, b. 159, 1. 9.

[32] Pagègių apskrities ịvairios vokiečių ekonominès draugijos. LCVA, f. 378, ap. 12, b. 463, 1. 1-2.

[33] Pranešimai apie Lietuvos vokiečius ir Kulturverbando veiklą. LCVA, f. 377, ap. 9, b. 113, 1. 3.

[34] Sommer R. ir Geleris B. Prekybos ir pramonès reikmenys. KAA, f. 209, ap. 5, b. 813, 1. 1.

[35] Vokiečių smulkaus kredito bankas. KAA, f. 209, ap. 2, b. 8796, 1. 2.

[36] Akc. b-vè „Tilka“ Kaunas-Šančiai. Tautos ūkis, 1930, Nr. 4, p. 132-133.

[37] Ar ilgai leisim vokiškoms firmoms save išnaudoti? Tẻvu žemé, 1935, birželio 18, Nr. 24-25, p. 3.

[38] BILYS, Akiras. Lietuvos miestai ir miesteliai: Marijampolès apskritis. T. 6. Kaunas, 1937, p. 150.

[39] DROMUTA, R. Von der Ropp’ų „nuopelnai“ Lietuvai. Tèvu žemé, 1935, vasario 2, Nr. 5, p. 2.

[40] Gana užsienių avalinès! Tẻvų žemé, 1935, kovo 20, Nr. 11-12, p. 8.

[41] Gana vokiškų nuodų. Tèvų žemé, 1935, kovo 30, Nr. 13, p. 8.

[42] HEBERLE, Rudolf. Die Deutschen in Litauen. Stuttgart: Ausland und Heimat Verlags Aktiegesellschaft, 1927, S. 6.

[43] Kam reklamuot vokiškas prekes. Tëvų žemè, 1935, vasario 16, Nr. 7, p. 8.

[44] KARECKAS, J. Nuolaidumu vokiečių neatsiginsim. Tẻvu žemé, 1935, sausio 26, Nr. 4, p. 2.

[45] Kodèl kapitalai atitenka svetimšaliams? Tẻvu žemè, 1935, birželio 8, Nr. 23, p. 1.

[46] Kodèl mes atsilikę? Verslas, 1935, kovo 2, Nr. 12, p. 2.

[47] Kommerzienrat Richard A. Tillmanns. Deutsche Nachrichten für Litauen, 1932 07 30, Nr. 30 , S. 1.

[48] Latvijoje prekyba tvarkoma kur kas energingiau. Verslas, 1936, rugpjūčio 6, Nr. 32, p. 1.

[49] Lietuvos gyventojai. Pirmojo $1923 \mathrm{~m}$. rugsèjo $17 \mathrm{~d}$. visuotino gyventoju surašymo duomenys. Kaunas, 1924.

[50] Lietuvos pramone ir jos gamyba 1930 m. Kaunas: „Spindulio“ b-vès spaustuvė, 1931, p. 113117.

[51] Lietuvos prekyba, pramone ir finansai 1925-1926. Kaunas: „Naudos“ b-vè, 1927, p. 92. 
[52] Lietuvos prekybos, pramonés ir finansu veikejju albumas. Kaunas, 1929, p. 28.

[53] Lietuvos statistikos metraštis 1927-1928 m. Kaunas: akc. b-vè „Spindulio“ spaustuve, 1929, p. 24.

[54] Lietuvos statistikos metraštis 1932 m. Kaunas: akc. b-vè „Spindulio“ spaustuve, 1933. p. 16.

[55] Lietuvos statistikos metraštis 1933 m. Kaunas: akc. b-vè „Spindulio“ spaustuvė, 1934, p. 19.

[56] Lietuvos statistikos metraštis 1934 m. Kaunas: akc. b-vè „Spindulio“ spaustuvė, 1935, p.19.

[57] Lietuvos statistikos metraštis 1936 m. Kaunas: akc. b-ve „Spindulio“ spaustuvė, 1937, p. 20.

[58] Lietuvos statistikos metraštis 1938 m. Kaunas: Centralinis statistikos biuras, 1939, p. 20.

[59] Mūsų pramonès įstaigos „Tilka“. Lietuvos žinios, 1928, gegužès 18, Nr. 107, p. 4.

[60] Pakeiskim tos gatvès pavadinimą [Šančiuose Vokiečių gatvę - I. J.]. Tẻvų žemè, 1935, balandžio 17, Nr. 15-16, p. 8.

[61] Per daug vertinam visa kas vokiška. Tëvu žemè, 1935 , vasario 16, Nr. 7, p. 8.

[62] Pramonè reikia atlietuvinti. Verslas, 1936, rugsèjo 17, Nr. 38, p. 2.

[63] Richardą Tillmannsą palydint. Rytas, 1932, liepos 27, Nr. 152, p. 2.

[64] Studentai prieš vokiečių šmeižtus. Tẻvu žemè, 1935, balandžio 7, Nr. 14, p. 4.

[65] ŠVYTURYS, K. Budekkim, vokietybè plinta. Tẻvu žemé, 1934, liepos 15, Nr. 12, p. 6.

[66] VOSYLIUS, K. Ekonominiai lietuvių reikalai ir svetimtaučiai. Naujoji Romuva, 1938, gruodžio 18, Nr. 50, p. 956-957.

[67] ANGERMANN, Norbert. Die Deutschen in Litauen. Ein geschichtlicher Überblick. Lüneburg: Institut Norddeutsches Kulturwerk, 1996, S. 12.

[68] ANUŠAUSKAS, Arvydas. Lietuvos Slaptosios tarnybos, 1918-1940. Vilnius, 1998, p. 220.

[69] ARBUŠAUSKAITĖ, Arūnè L. Gyventojų mainai tarp Lietuvos ir Vokietijos pagal 1941 m. sausio 10 d. sutartį. Klaipèda, 2002.

[70] ARLAUSKAS, Pranas. Vokiečių ūkininkų repatriacija ir sugrižimas. Ūkininkas, 1991, Nr. 22, p. 4.

[71] CROIX, Alexander. Die Umsiedlung im Spiegel der Zahlen. Heimatgruss, 1961, S. 58-59.

[72] FUCHS, Klaus. Das Image der ethnischen Minderheiten in den Berichten des litauischen Staatsschutzes 1934. Annaberger Annalen, 2003, Nr. 11.

[73] FUCHS, Klaus. Die Ermittlungen von Matas Krygeris zum deutschnationalen Finanzwerk im Memelgebiet, 1935. Annaberger Annalen, 2005, Nr. 13, S. 83-157.

[74] HERMANN, Arthur. Lietuviu ir vokiečiu kaimynystè. Vilnius: Baltos lankos, 2000, p. 248.

[75] JAKUBAVIČIENĖ, Ingrida. Lietuvos vokiečių Kulturverbando ryšiai su Vokietija 19331940 metais. Istorija, 2006, Nr. 64, p. 40-51.

[76] JUŠKA, Albinas. Apie lietuvių ir vokiečių santykius tarpukaryje. Annaberger Annalen. Jahrbuch über Litauen und deutsc-litauische Beziehungen, Bd. 1, 1993, s. 23-26.

[77] KAUBRYS, Saulius. National minorities in Lithuania. An Outline. Vilnius: Vaga, 2002.

[78] LUKŠIONYTĖ-TOLVAIŠIENĖ, Nijolè. Gubernijos laikotarpis Kauno architektūroje. Kaunas, 2001, p. 105.

[79] MARDOSA, Jonas. Tautiniai santykiai Lietuvos respublikos kaimuose ir miesteliuose 19201940 metais. Etnine kultūra ir tapatumo išraiška. Konf. medžiaga. Vilnius, 1999, p. 105.

[80] STOSSUN, Harry. Litauen vom Ersten bis zum Ende des zweiten Welkriegs. In: J. Rogal, (hrsg.). Deutsche Geschichte im Osten Europas. Land der großen Ströme. Von Polen nach Litauen. Berlin, 1999, S. 473.

[81] Sveikatos draudimo Lietuvoje istorija. Prieiga per internetą: <http://www.ktlk.lt/gyventojams/ apsd/istorija/> (žiūrèta 201103 07)

[82] TERLECKAS, Vladas. Lietuvos bankininkystès istorija 1918-1941. Vilnius, 2000. 
[83] VASKELA, Gediminas. Žemès reforma Lietuvoje 1919-1940 m. Vilnius, 1998, p. 320.

[84] VENSKŪNAS, Vytautas. Pasikeitimas repatriantais 1941 metais. Laikas ir ìvykiai, 1989, Nr. 14, p. 16.

[85] ŽOSTAUTAITĖ, Petronèlè. Klaipédos kraštas 1923-1939. Vilnius, 1992, p. 54-55.

[86] ŽOSTAUTATÉ, Petronèlè. Klaipèdos krašto bankai ir kredito įstaigos 1919-1939 metais. Lietuvos ükis, 1991, Nr. 6.

[87] ŽOSTAUTATÉ, Petronèlè. Klaipèdos krašto ekonomika ir kultūra 1923-1939 m. (1. Pramonè). LTSR MA darbai, 1972, A ser, T. 4.

[88] ŽUKAS, Julius. Klaipédos krašto ekonomine raida XIX a. antroje pusèje - XX a. pirmoje pusèje. Disertacijos rankraštis. Klaipèdos universitetas, 2010.

[89] ŽUKAS, Julius. Stambiosios pramonès atsiradimas Klaipedos krašte (XIX amžiaus pabaiga - XX amžiaus pradžia). Lietuvos istorijos studijos, 2008, Nr. 19, p. 41-50.

INGRIDA JAKUBAVIČIENÉ

\title{
Germans in the Lithuanian economy of the 3rd and 4th decades of the 20th century
}

\begin{abstract}
Summary
In the 3rd decade, the output of German businesses was quite humble as the majority of German community worked in the agricultural sector or ran small enterprises. They developed their business without any financial aid from Germany. In the 3rd decade, Germans owned very few big companies or estates. Until 1934, the business environment for Germans was quite favourable. In 1935, after the trial against German Nazis from the Klaipeda region, Germans in Lithuania fell under pressure. At the same time, Lithuanians started taking actions to consolidate their weight in the economy.

In the 4th decade, the number of German enterprises and pieces of property owned by the minority increased due to the active involvement of Kulturverband, which turned into an organization interested not only in the cultural but also in the economic aspects of the community. With the help of Kulturverband, German farmers and owners of small businesses received financial aid from Germany. However, if compared with the economic situation of Germans in the Klaipeda region, Germans in the rest of Lithuania never had anything close to a dominant position in the business, received fewer financial injections and had to face competition in the market and national discrimination. Evolving business plans were disrupted in 1940 by the political decision of Germany to evict Germans from Lithuania.

Key words: Lithuanian German Cultural Union (Kulturverband), Germany, German community in Lithuania, Lithuanian economy
\end{abstract}

